\title{
Nitrification by Aflatoxigenic Strains of Aspergillus flavus and Aspergillus parasiticus
}

\author{
By C. N. SHIH, ELIZABETH MCCOY AND E. H. MARTH \\ Department of Food Science, Department of Bacteriology and The Food Research \\ Institute, University of Wisconsin-Madison, Wisconsin 53706, U.S.A.
}

(Received 29 April 1974)

\begin{abstract}
SUMMARY
Four toxigenic strains each of Aspergillus flavus and A. parasiticus were grown in Schmidt's peptone-glucose medium to determine their ability to carry out nitrification and in a yeast extract-sucrose (YES) medium to test their toxigenicity. Two nitrifying strains each of $A$. flavus and $A$. parasiticus were grown in YES medium to examine their ability to form aflatoxin. A steam-distillation method was used to determine ammonium-, nitrite- and nitrate-nitrogen, whereas thin-layer chromatography and fluorometry served to measure afiatoxin content of broths. All eight toxigenic strains produced nitrate in Schmidt's and YES media when incubated without shaking. Shaking of cultures tended to increase the amount of nitrate formed in Schmidt's but not in YES medium. Amounts of aflatoxin produced varied with media and methods of incubation. All four nitrifying strains formed aflatoxin in YES medium. Toxigenic and nitrifying strains that gave high yields of aflatoxin did not always produce high levels of nitrate.
\end{abstract}

\section{INTRODUCTION}

Biological oxidation of ammonia to nitrite and of nitrite to nitrate in natural environments was formerly ascribed to the chemo-autotrophic nitrifying bacteria, especially those in the genera Nitrosomonas and Nitrobacter, until it was observed that certain fungi and heterotrophic bacteria were also able to produce nitrate (Aleem, Lees \& Lyric, I964; Eylar \& Schmidt, 1959; Schmidt, 1954). The nitrifying activity of Aspergillus flavus was first reported by Schmidt (1954), who observed that nitrate was produced in culture filtrates when the mould grew on a peptone medium. Results of later studies showed that many strains of $A$. flavus, and some of $A$. wentii and of $A$. oryzae, can also generate nitrite and nitrate from reduced forms of nitrogen (Doxtader \& Alexander, 1966; Eylar \& Schmidt, 1959; Marshall \& Alexander, 1961).

The nitrifying action of aspergilli is an example of nitrification by heterotrophic microorganisms that occurs in nature. Information on nitrification by these organisms can lead to a better understanding of nitrification by heterotrophic organisms in general and of the process by which fungi can oxidize ammonia (Molina \& Alexander, 197I ; Schmidt, 1954). Eylar \& Schmidt (1959) examined 1300 heterotrophic micro-organisms isolated from soil and found that fungi were the most numerous and most active nitrite producers. Most of these fungi (I6 of I8) were identified as A. flavus. Hora \& Iyengar (1960) examined Indian soils and found that aspergilli and penicillia were the main groups of nitrifying fungi. The aspergilli produced nitrite and nitrate from peptone, but penicillia produced nitrate only from nitrite.

Some moulds in the genus Aspergillus have also been studied extensively because they can 
form aflatoxins, the highly toxic metabolites primarily associated with $A$. flavus and $A$. parasiticus (Detroy, Lillehoj \& Ciegler, 1971 ; Marth, I967; Wogan, 1966). As stated earlier, A. flavus can produce nitrite and nitrate, compounds about which there is mounting concern as possible toxicants in water, feeds and foods. Nitrites and nitrates have been associated with certain animal and human health problems (Keeney, 1970). In considering these two characteristics of certain aspergilli and their frequent association with animal feeds, human foods and soil, it was believed useful to determine if a relationship exists between the ability to produce aflatoxin and the capacity to form nitrite and nitrate. Hence, the present study was designed: (i) to examine nitrification and aflatoxin production by strains of $A$. flavus and $A$. parasiticus under different cultural conditions and thus to determine if formation of one is related to production of the other; and (ii) to test if the two processes could occur simultaneously in some media and under certain conditions.

\section{METHODS}

Cultures. Four known toxigenic strains each of $A$. flavus (NRRL3I6r, NRRL325I, NRRL3353 and NRRL3494) and $A$. parasiticus (NRRL465, NRRL2999, NRRL3000 and NRRL33 I5) were used in this study. All were obtained from the Northern Regional Research and Development Division, U.S. Department of Agriculture, Peoria, Illinois, U.S.A. In addition, two known nitrifying strains each of A. flavus (WB4955 and WB4942) and A.parasiticus (WB465 and WB4I 23), obtained from K. B. Raper, Department of Bacteriology, University of Wisconsin, Madison, Wisconsin, U.S.A., were studied for their ability to form aflatoxin.

Preparation of spore suspensions. Moulds were grown on slants of mycological agar (Difco) for 7 days at $28^{\circ} \mathrm{C}$. Spores were harvested by adding sterile distilled water and a drop of Leconal wetting agent (Laboratory Equipment Co., St. Joseph, Michigan, U.S.A.) to the slants. Each suspension was adjusted to contain approximately $7.6 \times 10^{6}$ spores $/ \mathrm{ml}$ (an extinction of 0.50 at $550 \mathrm{~nm}$ ) (Spectronic 20, Bausch and Lomb, Rochester, New York, U.S.A.) for use as inoculum.

Media and cultural conditions. Schmidt's peptone-glucose medium (Schmidt, 1960) was used to study nitrification. The liquid yeast extract-sucrose (YES) medium of Davis, Diener \& Eldridge (1966) served to study aflatoxin production.

Both media ( $100 \mathrm{ml}$ in a $500 \mathrm{ml}$ Erlenmeyer flask) were inoculated with $\mathrm{I} \mathrm{ml}$ of the spore suspension and incubated without shaking for 14 days or with shaking (rotary shaker with $2.5 \mathrm{~cm}$ radius from B. F. Gump Co., Chicago, Illinois, U.S.A., operated at $390 \mathrm{rev} . / \mathrm{min}$ ) for 6 or 7 days at $28 \pm \mathrm{I}{ }^{\circ} \mathrm{C}$.

Determination of nitrogen compounds. Steam distillation methods of Bremner \& Keeney ( 1965 ) were used to determine ammonium nitrogen and nitrogen from nitrite plus nitrate. A modification of the Griess-Ilosvay method (Bremner, 1965) was used to determine nitrite nitrogen on another sample of culture filtrate. Subtracting the value obtained for nitrite nitrogen from that obtained for the combined nitrate and nitrite nitrogen yielded the value for nitrate nitrogen.

Determination of aflatoxin. Either $10 \mathrm{ml}$ of filtrate from cultures grown in YES broth or $50 \mathrm{ml}$ from cultures grown in peptone-glucose broth were used for aflatoxin analysis. Two parts of chloroform were added to one part of sample to extract the aflatoxin. Aflatoxins $\mathbf{B}_{1}$ and $G_{1}$ were determined by thin-layer chromatography and fluorometry as described by Shih \& Marth (1969). This method permits detection of $1 \cdot 0 \times 10^{-3} \mu \mathrm{g}$ aflatoxin $B_{1}$ or $G_{1} / \mathrm{ml}$ material applied to the chromatographic plate. 
Table I. Nitrogen compounds and aflatoxin in two media inoculated with A. flavus and incubated without shaking

\begin{tabular}{|c|c|c|c|c|c|c|}
\hline \multirow{2}{*}{$\begin{array}{l}\text { Strain of } \\
\text { A. flavus }\end{array}$} & \multirow{2}{*}{$\underset{(\mu \mathrm{g} / \mathrm{ml})}{\operatorname{Ammonia}-N}$} & \multirow{2}{*}{$\begin{array}{l}\text { Nitrite-N } \\
(\mu \mathrm{g} / \mathrm{ml})\end{array}$} & \multirow{2}{*}{$\begin{array}{c}\text { Nitrate-N } \\
(\mu \mathrm{g} / \mathrm{ml})\end{array}$} & \multicolumn{2}{|c|}{ Aflatoxin $(\mu \mathrm{g} / \mathrm{ml})$} & \multirow[b]{2}{*}{ pH } \\
\hline & & & & $\mathbf{B}_{1}$ & $\mathbf{G}_{1}$ & \\
\hline \multicolumn{7}{|c|}{ Peptone-glucose medium* } \\
\hline Control & $5 \cdot 6$ & 0.01 & $I \cdot 6$ & ND & ND & \\
\hline NRRL316I & $124 \cdot 6$ & 0.06 & $2 \cdot 3$ & ND & ND & \\
\hline NRRL325I & I I I 0 & 0.08 & $2 \cdot 4$ & ND & ND & o \\
\hline NRRL3353 & $138 \cdot 0$ & 0.65 & $3 \cdot 4$ & $1.6 \times 10^{-3}$ & ND & \\
\hline NRRL3494 & I $10 \cdot 8$ & 0.13 & $2 \cdot 3$ & $1.0 \times 10^{-3}$ & ND & \\
\hline \multicolumn{7}{|c|}{ Yeast extract-sucrose medium $\dagger$} \\
\hline Control & $70 \cdot 2$ & 0.04 & $3 \cdot 2$ & ND & ND & \\
\hline NRRL3 161 & $33 \cdot 2$ & ND & $6 \cdot 2$ & $29 \cdot 0$ & 133.5 & \\
\hline NRRL325I & $32 \cdot 0$ & ND & $6 \cdot 1$ & 14.5 & 3.0 & \\
\hline NRRL3353 & $42 \cdot 8$ & ND & 5.4 & $2 \cdot 3$ & $2 \cdot 4$ & \\
\hline NRRL3494 & $44 \cdot 3$ & ND & $5 \cdot 8$ & $25 \cdot 0$ & ND & $5 \cdot 90$ \\
\hline
\end{tabular}

ND, not detected.

* Incubated for 14 days at $28 \pm 1{ }^{\circ} \mathrm{C}$, optimum for nitrate or nitrite production.

$\dagger$ Incubated for 7 days at $28 \pm \mathrm{I}^{\circ} \mathrm{C}$, optimum for aflatoxin formation.

\section{RESULTS}

Aspergillus flavus. When the four strains of $A$. flavus known to be toxigenic were inoculated into the peptone-glucose medium and incubated without shaking for 14 days, only two strains produced detectable aflatoxin $B_{1}$ (Table I). The strain, NRRL3353, that produced the most aflatoxin also yielded the greatest amounts of nitrite nitrogen $(0.64 \mu \mathrm{g} / \mathrm{ml})$ and nitrate nitrogen ( $1.8 \mu \mathrm{g} / \mathrm{ml})$. Other strains produced less nitrite- and nitrate-nitrogen but all strains ammonified the peptone, as is evident from both the high $\mathrm{pH}$ and high ammonia-nitrogen values.

Growth of the same organisms in the YES medium resulted in reduced amounts of ammonia-nitrogen, an acidic $\mathrm{pH}$, and substantially greater yields of aflatoxins and nitratenitrogen. Greatest depletion of ammonium-nitrogen was accompanied by highest production of nitrate-nitrogen. The strain, NRRL3I6I, that produced most aflatoxin also formed the most nitrate-nitrogen, whereas the strain, NRRL3353, that produced the least aflatoxin also yielded the least nitrate-nitrogen. However, any relationship between these two characteristics is less clear when the other strains of $A$. flavus are considered.

Incubation with shaking (Table 2) slightly enhanced aflatoxin production in the peptoneglucose medium but was often somewhat detrimental to formation of aflatoxin, particularly $G_{1}$, in the YES medium. Shaking enhanced ammonification by all strains in the peptoneglucose medium, but had only minimal effects on production of nitrite-nitrogen and nitratenitrogen. Depletion of ammonia-nitrogen was increased over that observed with incubation without shaking when the YES medium was used but there was no concurrent increase in nitrate-nitrogen production by three of the four toxigenic strains of $A$. flavus.

Aspergillus parasiticus. The four strains of $A$. parasiticus, when grown without shaking in the peptone-glucose medium (Table 3), produced somewhat more aflatoxin than did the strains of $A$. flavus (Table I). Additionally, the strains of $A$. parasiticus were more active ammonifiers than were the $A$. flavus strains. Nitrite-nitrogen and nitrate-nitrogen were produced from the peptone-glucose medium by all strains examined. Strain NRRL33I5 produced both the highest yield of nitrite-nitrogen and of aflatoxin. 
Table 2. Nitrogen compounds and aflatoxin in two media inoculated with A. flavus and incubated with shaking

\begin{tabular}{|c|c|c|c|c|c|c|}
\hline \multirow[b]{2}{*}{$\begin{array}{l}\text { Strain of } \\
\text { A. flavus }\end{array}$} & \multirow[b]{2}{*}{$\underset{(\mu \mathrm{g} / \mathrm{ml})}{\operatorname{Ammonia}-\mathrm{N}}$} & \multirow{2}{*}{$\begin{array}{l}\text { Nitrite-N } \\
(\mu \mathrm{g} / \mathrm{ml})\end{array}$} & \multirow{2}{*}{$\begin{array}{c}\text { Nitrate-N } \\
(\mu \mathrm{g} / \mathrm{ml})\end{array}$} & \multicolumn{2}{|c|}{ Aflatoxin $(\mu \mathrm{g} / \mathrm{ml})$} & \multirow[b]{2}{*}{$\mathrm{pH}$} \\
\hline & & & & $\mathbf{B}_{1}$ & $\mathbf{G}_{1}$ & \\
\hline \multicolumn{7}{|c|}{ Peptone-glucose medium* } \\
\hline Control & $5 \cdot 6$ & 0.01 & $I \cdot 6$ & ND & ND & \\
\hline NRRL3 I 6 I & $162 \cdot 8$ & 0.07 & $2 \cdot 0$ & $4.4 \times 10^{-3}$ & $1 \cdot 1 \times 10^{-3}$ & \\
\hline NRRL 325I & $139 \cdot 0$ & 0.04 & $2 \cdot 2$ & $2 \cdot 3 \times 10^{-3}$ & ND & $8 \cdot 7$ \\
\hline NRRL3353 & $169 \cdot 0$ & 0.50 & $5 \cdot 2$ & $5.7 \times 10^{-3}$ & $4.5 \times 10^{-3}$ & $8 \cdot 7$ \\
\hline NRRL3494 & $159 \cdot 0$ & 0.05 & $1 \cdot 6$ & $3.8 \times 10^{-3}$ & ND & \\
\hline \multicolumn{6}{|c|}{ Yeast extract-sucrose medium $\dagger$} & \\
\hline Control & $70 \cdot 2$ & 0.04 & $3 \cdot 2$ & ND & ND & \\
\hline NRRL3I6I & $13 \cdot 8$ & ND & $3 \cdot 6$ & $36 \cdot 0$ & $86 \cdot 4$ & \\
\hline NRRL325I & $13 \cdot 8$ & ND & $3 \cdot 3$ & $3 I \cdot I$ & $I \cdot O$ & \\
\hline NRRL3353 & $15 \cdot 1$ & ND & $5 \cdot 0$ & $2 \cdot 8$ & $I \cdot O$ & \\
\hline NRRL 3494 & 15.9 & ND & $7 \cdot 5$ & $13 \cdot 7$ & ND & \\
\hline
\end{tabular}

ND, Not detected.

* Incubated for 6 days at $28 \pm \mathrm{I}{ }^{\circ} \mathrm{C}$, optimum for nitrite or nitrate formation.

+ Incubated for 7 days at $28 \pm \mathrm{I}{ }^{\circ} \mathrm{C}$, optimum for aflatoxin production.

Table 3. Nitrogen compounds and aflatoxin in two media inoculated with $A$. parasiticus and incubated without shaking

\begin{tabular}{|c|c|c|c|c|c|c|}
\hline \multirow{2}{*}{$\begin{array}{l}\text { Strain of } \\
\text { A. parasiticus }\end{array}$} & \multirow[b]{2}{*}{$\underset{(\mu \mathrm{g} / \mathrm{ml})}{\text { Ammonia-N }}$} & \multirow[b]{2}{*}{$\begin{array}{c}\text { Nitrite-N } \\
(\mu \mathrm{g} / \mathrm{ml})\end{array}$} & \multirow[b]{2}{*}{$\begin{array}{l}\text { Nitrate-N } \\
(\mu \mathrm{g} / \mathrm{ml})\end{array}$} & \multicolumn{2}{|c|}{ Aflatoxin $(\mu \mathrm{g} / \mathrm{ml})$} & \multirow[b]{2}{*}{$\mathrm{pH}$} \\
\hline & & & & $\mathbf{B}_{1}$ & $\widehat{\mathrm{G}_{1}}$ & \\
\hline \multicolumn{7}{|c|}{ Peptone-glucose medium* } \\
\hline Control & $5 \cdot 6$ & 0.01 & $1 \cdot 6$ & ND & ND & $7 \cdot 20$ \\
\hline NRRL465 & $177 \cdot 9$ & 0.13 & $2 \cdot 5$ & $1.4 \times 10^{-3}$ & ND & $8 \cdot 45$ \\
\hline NRRL2999 & $146 \cdot 5$ & 0.08 & $2 \cdot 2$ & $2.4 \times 10^{-3}$ & ND & $8 \cdot 45$ \\
\hline NRRL3000 & 134.5 & 0.08 & $2 \cdot 9$ & $1 \cdot 2 \times 10^{-3}$ & $1 \cdot 0 \times 10^{-3}$ & $8 \cdot 40$ \\
\hline NRRL3315 & $141 \cdot 5$ & 0.50 & $2 \cdot 3$ & $3.6 \times 10^{-3}$ & $2.6 \times 10^{-3}$ & $8 \cdot 40$ \\
\hline \multicolumn{7}{|c|}{ Yeast extract-sucrose medium $\dagger$} \\
\hline Control & $70 \cdot 2$ & 0.04 & $3 \cdot 2$ & ND & ND & $6 \cdot 46$ \\
\hline NRRL465 & $17 \cdot 1$ & ND & 3.6 & $24 \cdot 0$ & $37 \cdot 5$ & $5 \cdot 40$ \\
\hline NRRL2999 & 10.9 & ND & $3 \cdot 4$ & $26 \cdot 0$ & $29 \cdot 5$ & $4 \cdot 00$ \\
\hline NRRL3000 & $12 \cdot 5$ & ND & $3 \cdot 4$ & 23.5 & $33 \cdot 0$ & $4 \cdot 20$ \\
\hline NRRL 3315 & $18 \cdot 9$ & ND & $5 \cdot 6$ & $22 \cdot 5$ & $54 \cdot 0$ & $5 \cdot 10$ \\
\hline \multicolumn{6}{|c|}{$\begin{array}{l}\mathrm{ND}, \text { Not detected. } \\
{ }^{*} \text { Incubated } \mathrm{I} 4 \text { days at } 28 \pm \mathrm{I}^{\circ} \mathrm{C} \text {. } \\
+ \text { Incubated } 7 \text { days at } 28 \pm \mathrm{I}^{\circ} \mathrm{C} \text {. }\end{array}$} & \\
\hline
\end{tabular}

Unshaken growth of $A$. parasiticus in the YES medium resulted in a marked increase in production of acid and aflatoxin, and the depletion of ammonia-nitrogen when compared with results obtained with the peptone-glucose medium. No nitrite-nitrogen could be detected and only one strain, NRRL33 I 5, produced an appreciable amount of nitrate-nitrogen under these conditions. The same strain also formed the most aflatoxin.

Incubation with shaking profoundly affected the behaviour of $A$. parasiticus during growth in the peptone-glucose medium (Table 4). Production of aflatoxin was depressed, except with strain NRRL 3315 but formation of ammonia-, nitrite-, and nitrate-nitrogen was generally increased. Two strains, NRRL465 and NRRL3315, produced substantial amounts of nitrite- 
Table 4. Nitrogen compounds and aflatoxin in two media inoculated with

A. parasiticus and incubated with shaking

\begin{tabular}{|c|c|c|c|c|c|c|}
\hline \multirow[b]{2}{*}{$\begin{array}{c}\text { Strain of } \\
\text { A. parasiticus }\end{array}$} & \multirow[b]{2}{*}{$\begin{array}{l}\text { Ammonia-N } \\
(\mu \mathrm{g} / \mathrm{ml})\end{array}$} & \multirow[b]{2}{*}{$\begin{array}{c}\text { Nitrite-N } \\
(\mu \mathrm{g} / \mathrm{ml})\end{array}$} & \multirow[b]{2}{*}{$\begin{array}{c}\text { Nitrate-N } \\
(\mu \mathrm{g} / \mathrm{ml})\end{array}$} & \multicolumn{2}{|c|}{ Aflatoxin $(\mu \mathrm{g} / \mathrm{ml})$} & \multirow[b]{2}{*}{$\mathrm{pH}$} \\
\hline & & & & $B_{1}$ & $\mathrm{G}_{1}$ & \\
\hline \multicolumn{7}{|c|}{ Peptone-glucose medium* } \\
\hline Control & $5 \cdot 6$ & 0.01 & $1 \cdot 6$ & ND & ND & $7 \cdot 20$ \\
\hline NRRL465 & $158 \cdot 0$ & $14 \cdot 00$ & $4 \cdot 4$ & ND & ND & $8 \cdot 60$ \\
\hline NRRL2999 & 153.0 & 0.63 & $3 \cdot 6$ & ND & ND & $8 \cdot 65$ \\
\hline NRRL3000 & $172 \cdot 3$ & 0.83 & $3 \cdot 6$ & ND & ND & $8 \cdot 70$ \\
\hline NRRL33I 5 & $182 \cdot 0$ & $11 \cdot 00$ & $7 \cdot 2$ & $5.8 \times 10^{-3}$ & $4.5 \times 10^{-3}$ & $8 \cdot 70$ \\
\hline \multicolumn{7}{|c|}{ Yeast extract-sucrose medium $\dagger$} \\
\hline Control & $70 \cdot 2$ & 0.04 & $3 \cdot 2$ & ND & ND & $6 \cdot 46$ \\
\hline NRRL465 & I $2 \cdot 6$ & ND & $5 \cdot 5$ & $20 \cdot I$ & $29 \cdot 7$ & $4 \cdot 60$ \\
\hline NRRL2999 & $9 \cdot 2$ & ND & $3 \cdot 3$ & $21 \cdot 4$ & $14 \cdot 2$ & $4 \cdot 20$ \\
\hline NRRL3000 & IO'I & ND & 3.0 & 25.5 & 10.8 & $4 \cdot 45$ \\
\hline NRRL331 5 & $9 \cdot 2$ & ND & $5 \cdot 7$ & 19.9 & $36 \cdot 0$ & 4.45 \\
\hline \multicolumn{7}{|c|}{$\begin{array}{l}\text { ND, Not detected. } \\
* \text { Incubated } 6 \text { days at } 28 \pm 1{ }^{\circ} \mathrm{C} \text {. } \\
\dagger \text { Incubated } 7 \text { days at } 28 \pm 1{ }^{\circ} \mathrm{C} \text {. }\end{array}$} \\
\hline
\end{tabular}

Table 5. Aflatoxin formed by Aspergillus cultures capable of nitrification

\begin{tabular}{|c|c|c|c|c|c|}
\hline \multirow[b]{2}{*}{ Cultures* } & \multirow{2}{*}{$\begin{array}{l}\text { Nitrate-N } \dagger \\
(\mu \mathrm{g} / \mathrm{ml})\end{array}$} & \multicolumn{4}{|c|}{ Aflatoxin $\ddagger(\mu \mathrm{g} / \mathrm{ml})$} \\
\hline & & $\mathbf{B}_{1}$ & $\mathbf{B}_{2}$ & $\mathrm{G}_{1}$ & $\mathrm{G}_{2}$ \\
\hline A. flavus WB4955 & $22 \cdot 5$ & 0.10 & ND & 0.24 & ND \\
\hline A. flavus WB4942 & $19 \cdot 4$ & 0.22 & ND & 0.30 & ND \\
\hline A. parasiticus WB465 & $6 \cdot 1$ & $21 \cdot 6$ & $1 \cdot 0$ & $56 \cdot 0$ & $5 \cdot 4$ \\
\hline A. parasiticus WB4I 23 & $4 \cdot I$ & 16.5 & $I \cdot 2$ & $33 \cdot 0$ & $2 \cdot 5$ \\
\hline
\end{tabular}

ND, Not detected.

* Cultures obtained from K. B. Raper, Department of Bacteriology, University of Wisconsin, Madison, Wisconsin, U.S.A.

$\dagger$ For previous data on nitrification by these strains, see Heimbrook (1969).

$\ddagger$ Aflatoxin recovered from cultures incubated without shaking for 7 days at $28 \pm \mathrm{I}{ }^{\circ} \mathrm{C}$ in a $500 \mathrm{ml}$ Erlenmeyer flask containing $100 \mathrm{ml}$ yeast extract-sucrose medium.

nitrogen and more nitrate-nitrogen than did the other two strains. A relationship between aflatoxin and nitrite-nitrogen production was not readily evident.

Incubation with shaking did not greatly affect depletion of ammonia-nitrogen when YES broth served as the growth medium. Production of aflatoxin was generally somewhat depressed and there were no appreciable effects on formation of nitrite- and nitrate-nitrogen. The four strains of $A$. parasiticus that formed appreciable amounts of nitrite- and nitratenitrogen in the peptone-glucose medium produced no nitrite-nitrogen and formed only small amounts of nitrate-nitrogen in the YES medium. The strain, NRRL33 I 5, that produced most nitrate-nitrogen also formed most aflatoxin under these conditions.

Formation of aflatoxin by known nitrifying cultures. Two strains of $A$. flavus and two of $A$. parasiticus, reported to be among the most active nitrifiers in these two species (Heimbrook, 1969), were examined for their ability to form aflatoxin (Table 5). All four strains formed aflatoxin in the YES medium. Cultures of $A$. flavus produced relatively large amounts of nitrate and small amounts of aflatoxin, whereas cultures of $A$. parasiticus produced small 
amounts of nitrate and relatively large amounts of aflatoxin. Furthermore, the cultures of $A$. parasiticus produced aflatoxins $B_{2}$ and $G_{2}$, whereas these toxins were not found in cultures of $A$. flavus. It is evident from these data that cultures previously known only for their nitrifying abilities can also form aflatoxin.

\section{DISCUSSION}

This study shows that all eight of the aspergilli known to be toxigenic were also nitrifiers when grown in a peptone-glucose medium. They produced only nitrate in the YES broth when incubated without shaking. When the same strains were incubated with shaking, some formed more nitrite and/or nitrate, whereas others produced only negligible amounts. Variation in the nitrifying capacity of $A$. flavus under different cultural conditions has also been observed by Schmidt (I960). It is noteworthy that all four $A$. parasiticus strains tested were capable of nitrification, and two of them (Table 4), strains NRRL465 and NRRL33 I 5, produced relatively large amounts of nitrite and nitrate. Nitrification by $A$.parasiticus has been previously recognized (Heimbrook, I969) but not fully evaluated. This activity, plus its aflatoxigenicity, poses serious questions about the role of $A$. parasiticus in the environment.

Formation of aflatoxin by $A$. flavus and $A$. parasiticus was poor in the peptone-glucose medium, and markedly better in the YES medium. The difference in aflatoxin formation in these two media may be influenced, in part, by the difference in $\mathrm{pH}$ values: $7 \cdot 2$ to 8.5 for the peptone-glucose medium, versus 4.0 to $6 \cdot 4$ for the YES medium. Detroy \& Hesseltine (I969) found synthesis of aflatoxin was favoured under acidic conditions ( $\mathrm{pH} 3.5$ to 5.0 ) and strongly diminished at pH 5.5 and above. Several investigators (Doxtader \& Alexander, I966; Marshall \& Alexander, 1962; Schmidt, 1960) have pointed out that a pH value above 7 is more favourable for nitrification than are $\mathrm{pH}$ values below $6 \cdot 0$. When the cultures were shaken, the amount of aflatoxin produced in the YES broth was generally reduced and the pattern of aflatoxin formation in the peptone-glucose medium was variable.

We also demonstrated that two strains each of $A$. flavus and A.parasiticus, previously known only for their ability to nitrify, also produced aflatoxin when tested in the YES medium; the strains of $A$. parasiticus produced most aflatoxin.

Our results demonstrate that the capacity for nitrification and for aflatoxigenicity can exist in the same strains of aspergilli. Hence, these widely distributed moulds might produce nitrite and nitrate in addition to aflatoxin, so that all of these toxicants could enter water and food from the environment.

This research was supported by the College of Agricultural and Life Sciences, University of Wisconsin-Madison, and by Public Health Service Grant FDoor 43 from the Food and Drug Administration. The authors thank Dr D. R. Keeney, Department of Soil Science, University of Wisconsin-Madison, for his assistance in measuring nitrogen compounds.

\section{REFERENCES}

Aleem, M. I, Lees, H. \& LyRIC, R. (I964). Ammonium oxidation by cell-free extracts of Aspergillus wentii. Canadian Journal of Biochemistry 42, 989-998.

Bremner, J. M. (1965). Inorganic forms of nitrogen. In Methods of Soil Analysis. Part 2. Chemical and microbiological properties. Madison: American Society of Agronomics.

Bremner, J. M. \& KeENEY, D. R. (I965). Steam distillation methods for determination of ammonium, nitrate and nitrite. Analytica chimica acta 32, 485-495. 
DAVIS, N. D., Diener, U. L. \& Eldridge, D. W. (1966). Production of aflatoxin $\mathrm{B}_{1}$ and $\mathrm{G}_{1}$ by Aspergillus flavus in a semisynthetic medium. Applied Microbiology 14, 378-380.

Detroy, R. W. \& Hesseltine, C. W. (1969). Net synthesis of ${ }^{14} \mathrm{C}$-labeled lipids and aflatoxins in resting cells of Aspergillus parasiticus. Developments in Industrial Microbiology 10, 127-1 33.

Detroy, R. W., LlLLeHoJ, E. B. \& Ciegler, A. (197I). Aflatoxin and related compounds. In Microbial Toxins. vol. 6. Edited by A. Ciegler, S. Kadis and S. J. Ajl. New York: Academic Press.

DoXTADER, K. G. \& ALEXANDER, M. (1966). Role of 3-nitropropionic acid in nitrate formation by Aspergillus flavus. Journal of Bacteriology 91, 1 186-I 191.

EyLAR, O. R. \& SCHMIDT, E. L. (I959). A survey of heterotrophic micro-organisms from soil for ability to form nitrite and nitrate. Journal of General Microbiology 20, 473-48I.

HeimbrooK, M. E. (1969). Nitrification potential in the genus Aspergillus. M.S. thesis, University of Wisconsin, U.S.A.

HoRA, T. S. \& IYENGAR, M. R. S. (1960). Nitrification by soil fungi. Archiv für Mikrobiologie 35, 252-257.

KEENEY, D. R. (1970). Nitrates in plants and water. Journal of Milk and Food Technology 33, 425-432.

MARShall, K. C. \& AleXANDER, M. (1961). Fungi active in heterotrophic nitrification. Canadian Journal of Microbiology 7, 955-957.

Marshall, K. C. \& AleXANDer, M. (1962). Nitrification by Aspergillus flavus. Journal of Bacteriology 83 , 572-578.

MARTH, E. H. (1967). Aflatoxins and other mycotoxins in agricultural products. Journal of Milk and Food Technology 30, 192-198.

Molina, J. A. E. \& AleXANDer, M. (1971). Formation of nitrate from 3-nitropropionate by Aspergillus flavus. Journal of Bacteriology I05, 489-493.

SCHMid, E. L. (1954). Nitrate formation by a soil fungus. Science, New York 1x9, 187-189.

Schmid, E. L. (1960). Cultural conditions influencing nitrate formation by Aspergillus flavus. Journal of Bacteriology 79, 553-557.

SHIH, C. N. \& MARTH, E. H. (1969). Improved procedures for measurement of aflatoxins with thin-layer chromatography and fluorometry. Journal of Milk and Food Technology 32, 213-21 7.

WogAn, G. N. (1966). Chemical nature and biological effects of the aflatoxins. Bacteriological Reviews 30 , $460-470$. 